\title{
PERSPEKTIF AL-QUR'AN TENTANG TADABBUR
}

\author{
Oleh: Amir Hamzah ${ }^{1}$ \\ ${ }^{1}$ Institut Agama Islam Muhammadiyah Sinjai, \\ Jl.Sultan Hasanuddin. No. 20 Balangnipa, Sinjai \\ E-Mail:puangamirhamzahgmail.com, Tlp.: +6282188783286
}

\begin{abstract}
Abstrak
Penelitian ini bertujuan untuk mengungkap makna tadabbur dalam pandangan al-Qur'an. Metode kajian yang digunakan adalah dengan kajian tematik, sebuah metode yang lazim digunakan untuk mengungkap perspektif al-Qur'an terkait sebuah tema. Setelah menetapkan tema tadabbur, penelusuran terhadap ayat-ayat terkait dilakukan guna untuk mengetahui makna tadabbur dengan akurat. Selanjutnya untuk melengkapi data dalam kajian ini, dikemukakan juga beberapa pendapat mufassir. Akhirnya, hasil penelitian ini mengungkapkan bahwa al-Qur'an bukan hanya teks yang dibaca, namun lebih dari itu ia adalah firman Allah yang harus ditaddaburi. Artinya, setelah al-Qur'an dibaca, dihafal, atau bahkan ditafsirkan, sebagai muslim, sejatinya ketiga unsur ini diwujudkan dengan tindak laku sebagaimana yang diinginkan oleh ayat-ayat-Nya.
\end{abstract}

\section{Kata Kunci: Perspektif al-Qur'an, Tadabbur}

\section{PENDAHULUAN}

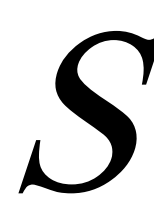

ālih li kulli zamān wa makān. Sekiranya ini menjadi gambaran paling tepat untuk mendeskripsikan kehadiran al-Qur'an di tengah penganutnya. Sejak zaman al-Làta dan al'Uzza masih setia di sisi ka'bah hingga kemudian kedua berhala terbesar di masanya itu hanya menyisakan nama saja, al-Qur'an masih tetap konsisten dengan nama beserta segala elemennya, sampai kapanpun itu. Bahkan, semakin berkembang zaman semakin pula al-Qur'an menampilkan sisinya yang tidak terbantahkan, semakin menunjukkan kemukjizatannya yang salah satunya dibuktikan melalui penemuan-penemuan ilmiah modern.

Secara fisik, al-Qur'an tentu tidak akan hilang. Demikian karena Allah Swt. sendiri telah menjaminnya (QS. al-Ḥijr/15: 9):

Terjemahnya:

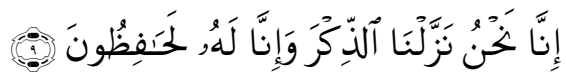

"Sesungguhnya Kamilah yang menurunkan al-Qur'an, dan pasti Kami (pula) yang memeliharanya" (Kemenag RI, 2012: 262).

Penjagaan Allah terhadap al-Qur'an betul-betul sangat istimewa. Keistimewaan tersebut oleh ulama tafsir diungkap melalui pemahaman mendalam terhadap kata innā pada kalimat wa innā lahu lạ̣ăfizūun. Kata innā dalam kalimat tersebut berbicara mengenai siapa yang menjaga al-Qur'an sehingga kepunahannya mustahil terjadi. Mengapa dalam konteks ini Allah menggunakan kata jamak (plural) bukan mufrad (single) saja, yakni kata inni? Sekilas, bagi orang awam bisa saja diartikan 
bahwa Allah yang menjadi penjaga al-Qur'an berjumlah banyak dengan menggunakan kata innā. Padahal sesungguhnya bukan itu yang dimaksud, melainkan digunakannya kata innā menjadi isyarat bahwa Allah-tentu mahaesa--, bukan satu-satunya penjaga, tetapi manusia juga turut serta mengambil bagian untuk menjaga keutuhan al-Qur'an. Itulah mengapa dalam konteks ini menggunakan kata innā (plural) bukan inni (single). Keotentikan al-Qur'an sampai di sini tentu tidak lagi diragukan, karena jaminannya Allah langsung.

Tujuan diturunkannya al-Qur'an tidak lain sebagai hudan li al-nās (petunjuk bagi manusia). AlQur'an dalam hal ini tentu menjadi poros utama bagi segala tindak laku manusia. Meski pada kenyataannya tidak semua manusia, khususnya muslim mengambil al-Qur'an sebagai petunjuknya. Pertanyaannya, mengapa orang Islam tidak menjadikan al-Qur'an sebagai petunjuk? Bukankah sangat jelas perintahnya? Bukankah setiap rumah minimal satu mushaf al-Qur'an terdapat di dalamnya? Ternyata, petunjuk atau hidayah dalam bahasa lainnya seringkali disalahpahami. Hidayah itu sesungguhnya harus diupayakan bukan ditunggu. Banyak yang ingin mendapatkan hidayah begitu saja tetapi berdiam diri, enggan untuk mencari. Sesungguhnya di sinilah salah satu jawaban mengapa al-Qur'an terkadang masih sekedar menjadi bacaan bukan petunjuk.

Di antara hal yang bisa dilakukan sebagai bukti nyata kecintaan kita terhadap al-Qur'an adalah dengan cara membacanya. Nabi bahkan memberikan kabar gembira bahwa membaca meski satu huruf saja akan mendapatkan satu pahala yang kemudian satu pahala tersebut bernilai sepuluh kebaikan. Tetapi tentu saja sebagai seorang muslim, sekedar membaca belumlah dikatakan cukup, karena di samping itu, ada unsur lain yakni tadabbur. Tadabbur merupakan tingkatan tertinggi dari interaksi kita kepada al-Qur'an, dengan mempraktekkannya, al-Qur'an akan benar-benar menjadi petunjuk dalam hidup.

Dari sini, terlihat betapa pentingnya tadabbur sebagai sebuah interaksi tertinggi dengan alQur'an. Olehnya itu, terkait dengan tadabbur ini, penulis kemudian mencoba untuk menjelaskan makna tadabbur dalam al-Qur'an.

\section{PEMBAHASAN}

\section{A. Hakikat Makna Tadabbur dalam al-Qur'an}

\section{Definisi Tadabbur}

Secara etimologis, kata tadabbur berasal dari bahasa Arab, yakni دَبَر (dabara), terdiri dari huruf dāl, bā', dan rā. Ibnu Fāris dalam kitabnya Maqāyis al-Lughah mengartikan dengan penghujung bagi sesuatu, bisa juga berarti di belakang (Ibnu Fāris, 2008: 308). Pengertian ini juga sebagaimana dikemukakan oleh Ibnu Manzūr dalam kitabnya (Ibnu Manẓūr, 2003: 288). Selain itu, kata tadabbur berarti mengurus dan merenungkan kesudahan urusan itu (Ibrahim Musthafa dkk., t.th.: 269). Tadabbur dapat juga berarti memikirkan serta meneliti akibat di balik perkara. Di 
dalam kamus al-Munawwir dijelaskan bahwa tadabbur adalah memikirkan dan mempertimbangkan akibatnya (baik dan buruknya) (Ahmad Warson Munawwir, 1997: 384).

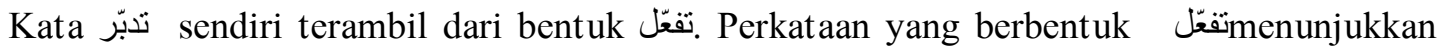
kepada perbuatan yang dilakukan dengan penuh usaha. Jelas di sini menunjukkan amalan tadabbur memerlukan usaha yang sungguh-sungguh untuk meneliti maksud ayat secara berulang-ulang kali sehingga mencapai pemahaman makna yang sempurna dan sesuai dengan kehendak Allah Swt.

Jika ditelusuri definisi yang diuraikan oleh ulama mengenai tadabbur secara bahasa, maka ditemukan bahwa tadabbur memiliki beberapa makna yakni, penghujung sesuatu, belakang, akhir, mengurus, merenungkan, dan mempertimbangkan akibat (baik atau buruk).

Sementara secara terminologis, tadabbur menurut Ibnu Kasīir adalah memahami makna lafal-lafal al-Qur'an, memikirkan apa yang ayat-ayat al-Qur'an tunjukkan tatkala tersusun, apa yang terkandung di dalamnya, apa yang menjadikan makna-makna al-Qur'an itu sempurna dari segala isyarat dan peringatan yang tidak tampak dalam lafal al-Qur'an, pengambilan manfaat oleh hati dengan tunduk di hadapan nasehat-nasehat al-Qur'an, patuh terhadap perintah-perintahnya, dan pengambilan ibrah darinya (Ibnu Kasìir, 2005: 11).

Al-Suyụtịi (w.1505 M) menambahkan bahwa bertadabbur harusnya membuat hati sibuk memikirkan makna atas ayat-ayat yang diucapkan, sehingga seseorang mampu mengetahui makna setiap ayat, memerhatikan perintah dan larangan seolah-seolah pasti menerima dan melaksanakannya. Jika seseorang merasa telah berbuat kesalahan pada masa lalu, maka ia meminta ampun dan beristigfar. Apabila sampai kepada ayat yang menceritakan tentang rahmat Allah dan kabar gembira, dia segera memohon kebaikan tersebut, atau apabila sampai kepada ayat azab dia memohon perlindungan agar dijauhkan daripadanya. Jika melewati ayat-ayat yang membesarkan dan mensucikan Allah, dia bertasbih dan bertahmid kepada-Nya, dan jika ayat-ayat yang berbentuk doa, dia berdoa dengan penuh tawadhu' dan pengharapan (Al-Suyūtî̀, 1974: 369).

Al-Zamakhsyari (w. 1144 M) berpendapat bahwa tadabbur ialah memberi perhatian terhadap makna-makna ayat dengan penuh penghayatan. Ia berlaku dengan memikirkan maksud ayat sehingga mencapai pengetahuan makna di balik ayat tersebut berdasarkan penakwilan yang sahih serta makna yang relevan (Al-Zamakhsyari, t.th.: 540).

Menurut al-Syaikh Abu Bakr al-Jurri, tadabbur ialah mengikuti dan beramal dengan ilmu alQur'an. Tadabbur bukanlah hanya menghafal huruf-huruf al-Qur'an, akan tetapi menyia-nyiakan batas-batasnya, sehingga salah seorang dari mereka mengatakan: Sungguh aku telah membaca alQur'an seluruhnya, dan aku tidak melewati satu huruf pun, padahal dia telah melewatkan seluruh al-Qur' an. Tidak terlihat padanya al-Qur'an, baik dalam tabiat maupun amalan (Hāsyim ibn 'ATi al-Ạ̣dāl, 2008: 15).

Ulama Kontemporer dalam hal ini berpendapat bahwa tadabbur ialah berfikir dengan menggunakan seluruh kemampuan akal dan dengan menggunakan pertanyaan-pertanyaan yang 
logis untuk mencapai pengertian yang baru, yang terkandung dalam nas al-Qur'an, yang sesuai dengan kaidah-kaidah bahasa Arab, baik yang menghubungkan antara kalimat-kalimat di dalam al-Qur'an, maupun yang menghubungkan antara surah-surah di dalam al-Qur'an (Hāsyim ibn 'ATi al-Ạ̣dāl, 2008: 15).

Di samping pengertian terminologis di atas, ada pula yang mengelompokkan pengertian tadabbur ini menjadi dua bagian, yakni tadabbur secara umum dan pengertian tadabbur terhadap al-Qur'an. Adapun pengertian tadabbur secara umum yakni satu pekerjaan merenungkan, mencermati, menghayati, memikirkan yang dilakukan seseorang secara sungguh-sungguh tentang akibat atau kesudahan dari suatu hal. Lalu kata tadabbur juga dipakai untuk pekerjaan yang bersifat memikirkan, merenungkan suatu hal. Sedangkan tadabbur terhadap al-Qur'an adalah memikirkan, menghayati akan isi kandungan al-Qur'an, baik berupa aqidah, hukum, etika, atau akhlak dan lain sebagainya, apa tujuannya, bagaimana kesudahan atau akibat yang ditimbulkan jika seseorang melakukan suatu hal dan apa akibatnya jika tidak melakukannya (Kemenag RI, 2010: 220).

Dari sekian definisi tadabbur yang diungkapkan oleh ulama, baik secara etimologi maupun terminologi, terlihat bahwa tidak ada perbedaan pemahaman dalam mendefinisikan arti tadabbur. Dari sini penulis dapat mengambil kesimpulan bahwa dalam tadabbur terdapat 2 hal yang perlu untuk digarisbawahi, yakni: (1) Adanya aktivitas berfikir dengan menggunakan seluruh kemampuan akal yang didorong dari hasil membaca ayat-ayat al-Qur'an, dari proses berfikir tersebut akan memunculkan pemahaman yang kemudian dihayati dan diamalkan. (2) Aktivitas berfikir yang dilakukan tidak hanya untuk menyimpulkan sebuah pemahaman, lebih dari itu berfikir dengan menggunakan seluruh kemampuan akal juga memikirkan tentang akibat atau kesudahan dari suatu hal yang difikirkan tersebut sehingga pemahaman yang dihasilkan memiliki manfaat.

\section{Terminologi Tadabbur dalam al-Qur'an}

Kata tadabbur dalam al-Qur'an dan yang seakar dengan itu ditemukan sebanyak 44 kali. Kata tadabbur dalam bentuk fi'il mudārī' disebut sebanyak 8 kali, dalam bentuk fi'il mā đ̆i disebut sebanyak 4 kali, dalam bentuk masdar disebut sebanyak 19 kali, adapun dalam bentuk ism fầil disebut sebanyak 13 kali.

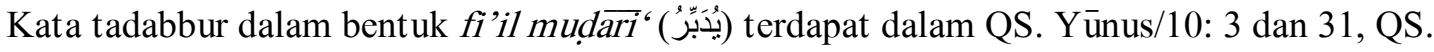
al-Ra'd/13: 2, dan QS. al-Sajadah/32: 5. Penggunaan kata tersebut di dalam al-Qur'an merupakan penggunaan dalam konteks penegasan Allah dalam mengatur segala urusan makhluk-Nya sebagaimana dalam firman-Nya:

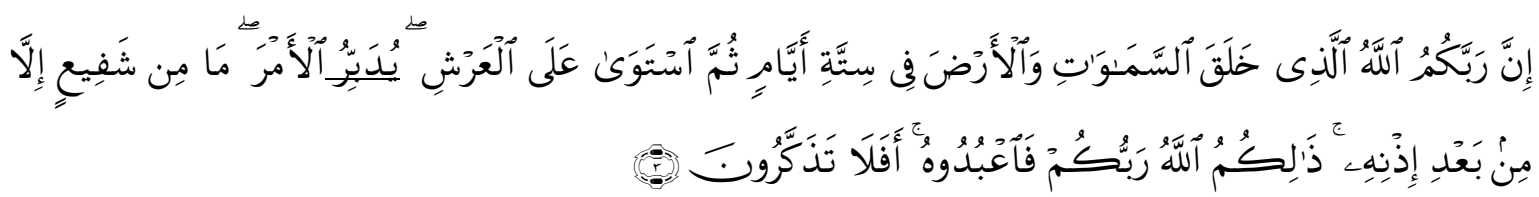


Terjemahnya:

"Sesungguhnya Tuhan kamu Dialah Allah yang menciptakan langit dan bumi dalam enam masa, kemudian Dia bersemayam di atas 'Arsy untuk mengatur segala urusan. Tidak ada yang dapat memberi syafa'at kecuali setelah ada izin-Nya. Itulah Allah, Tuhanmu, maka sembahlah Dia. Apakah kamu tidak mengambil pelajaran?" (Depag RI, 2012: 209).

Adapun kata يتدبرون (yatadabbarūna) pada QS. al-Nisā'/4: 82 dan QS. Muhammad/47: 24.

Lalu kata يدبرو (yaddabbarū) pada QS. al-Mu'minūn/23: 68 dan QS. Șād/38: 68 dan QS. Șād/38: 29. Beberapa kata tersebut meskipun sama-sama dalam bentuk fi'il mudariri dengan kata namun berbeda dalam arti dan penggunaan, kata يََََبََرُوْنَن difahami dalam arti berpikir tentang akhir atau kesudahan sesuatu. Ada juga yang memahaminya dalam arti berpikir tentang sesuatu setelah sesuatu yang lain. Sehingga, yatadabbarūna berarti perintah memerhatikan setelah sebelumnya telah memerhatikan (M. Quraish Shihab, 2009: 639). Allah memerintahkan kepada manusia untuk memerhatikan ayat-ayat Allah yang terdapat di dalam al-Qur'an. Bagi yang mengikuti perintah Allah ini akan berdampak atau berakhir dengan diberinya petunjuk oleh Allah dan dijanjikan kebahagiaan di akhirat kelak. Bagi yang tidak memerhatikan, Allah akan memberikan siksaanNya kepada mereka (M. Quraish Shihab, 2002: 1-2).

Selanjutnya adalah kata دَبُرُ/الدَبِرُ (dubur/ad-dubur) merupakan bentuk masdar dari kata dabara-yadburu-dabran/duburan/dubūran, disebut sebanyak 5 kali yaitu kata Yūsuf /12: 25, QS. Yūsuf/12: 27, QS. Yūsuf/12: 28, QS. al-Qamar/54: 45, dan QS. al-Anfāl/8: 16. Bentuk jamaknya adalah adbăr, disebut sebanyak 14 kali yaitu kata الأَدباَر/أَدْباًر pada QS. alAnfāl/8: 15, QS. al-Ahżāb/33: 15, QS. al-Fatḥ/48: 22, al-Ḥasyr/59: 12, QS. Qāf/50: 40, QS. at-

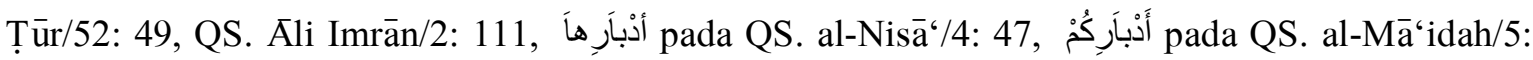

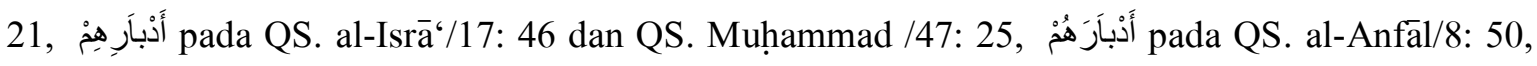
QS. Mụ̣ammad/47: 27, dan QS. al-Hijr/15: 65.

Secara bahasa, kata dubur berarti al-khalf, yakni belakang atau نَقيُُ القُبل (naqiidul qubl), yakni lawan dari depan. Di belakang sesuatu artinya 'yang mengiringi atau yang akhir', seperti فيُرُ أُنْنِهِ (duburu uzunihî), yakni di belakang telinganya.

Adapun dalam bentuk ism fá'il, disebut sebanyak 12 kali di dalam al-Qur'an, yaitu kata دَابِر pada QS. al-An’ām/6: 45, QS. al-A'rāaf/7: 72, QS. al-Anfāl/8: 7, dan QS. al-Hijr/15: 66. Kata pada QS. al-Naml/27: 10 dan QS. al-Qasas/28: 31, kata مُدْبِرِيْنَ pada QS. al-Taubah/9: 25, QS. alAnbiyā'/21: 57, QS. al-Naml/27: 80, QS. al-Rūm/30: 52, QS. al-Ṣāffāt/37: 90, dan QS. Mu'min/40: 33.

Kata دآبِر (dābir) digunakan sebagai lambang bagi arti 'membelakangi'. Artinya, 'tidak mempedulikan sesuatu atau meninggalkannya'. Dābir (kata sifat di dalam bentuk tunggal) hanya ditemukan empat kali di dalam al-Qur'an, yakni di dalam QS. al-An'ām/6: 45, QS. al-A'rāf/7: 72, QS. al-Anfāl/8: 7, dan QS. al-Hijr/15: 66. 
Kata dābir, berasal dari kata dabara yang pada mulanya berarti berakhirnya sesuatu. Apabila suatu pekerjaan telah selesai dilakukan, berarti pekerjaan itu akan ditinggalkan. Meninggalkan suatu pekerjaan berarti berbalik membelakangi pekerjaan. Dari sini, arti dabara berkembang menjadi membelakangi.

Kemudian arti dabara dengan segala derivasinya itu berkembang mengikuti perkembangan mengikuti konteks pemakaiannya. Misalnya, mengevaluasi kegiatan yang telah lalu disebut tadabbur. Seseorang yang menukilkan berita dari orang lain diungkapkan dengan redaksi دبّر الحديث (dabbara al-hadis) karena yang disampaikan itu merupakan ucapan seseorang yang telah berlalu. Agaknya, itulah sebabnya pengertian membelakangi sesuatu itu disebut dengan dābir.

Al-Raghīb al-Asfahānī (w. 1108 M) merinci lebih jauh arti kata dābir. Menurutnya, kata tersebut dapat dipakai dengan makna ism fá'il (kata sifat yang menunjuk kepada pelaku). Di sini kata tersebut harus diartikan sebagai membelakangi, dan bisa dengan makna ism maf' ūl (kata sifat yang menunjuk kepada objek), di sini kata tersebut harus diartikan sebagai yang dibelakangi. Dari segi lain, kata dābir dapat diartikan sebagai yang membelakangi dari segi waktu, membelakangi dari segi tempat, atau membelakangi dari segi jabatan. Namun semuanya itu baru merupakan pemakaian bahasa yang selalu berubah dengan berubahnya konteks pembicaraan (M. Quraish Shihab, 2007: 155-156).

Adapun kata مَدَبِّراتَ yang berposisi sebagai ism fá'il dari kata دَبَّرَ disebut hanya sekali, yaitu pada QS. al-Nāzi'àt/79: 5. Kata ini memberi arti mengatur, yang dimaksud sebagai pengatur ialah malaikat, sebagaimana firman-Nya:

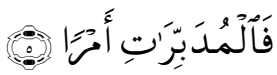

Terjemahnya:

"Dan (malaikat) yang mengatur urusan (dunia)" ( Depag RI, 2012: 584).

Sedangkan dalam bentuk fi'il mādí, disebut sebanyak 4 kali yaitu kata أدبر pada QS. alMa’ārij/70: 17, QS. al-Muddašsirir/74: 23, QS. al-Muddašsiri/74: 33, dan QS. al-Nāzi'āt/79: 22.

\section{Objek Tadabbur}

Setelah melalukukan penelusuran terkait dengan kata tadabbur dan derivasinya di dalam alQur'an, ditemukan bahwa tadabbur memiliki beberapa makna, yakni: 1) Dalam bentuk fi'il

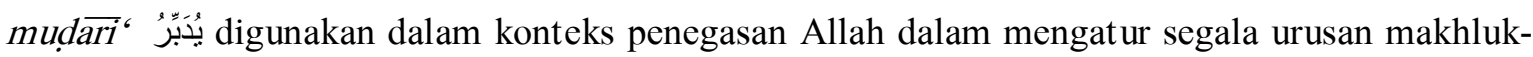
Nya. Adapun kata يتدبرون (yatadabbarūna) dan يدبروا (yaddabbarū) difahami dalam arti berpikir tentang akhir atau kesudahan sesuatu. Sehingga, yatadabbarūna berarti perintah memerhatikan

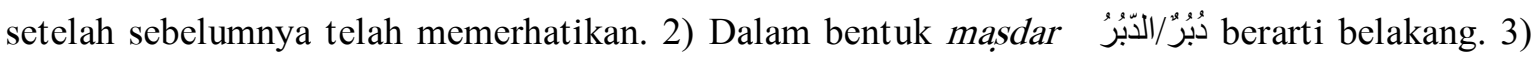
Dalam bentuk ism fá'il دَابِّ berarti berakhirnya sesuatu.

Dari pemaknaan di atas, dapat ditemukan sebuah kesimpulan bahwa tadabbur adalah sebuah aktifitas berpikir yang mendalam terhadap ayat-ayat Allah. Artinya bahwa manusia diperintahkan untuk berpikir tentang akhir yang menjadi kesudahan sesuatu, berarti pula bahwa berpikir di sini 
tidak hanya sekedar menjadi pemahaman dalam kepala saja, tetapi mengarah kepada aktualisasi nilai daripada proses berpikir tadi. Singkatnya, mengamalkan secara sadar hasil dari pembacaan kita terhadap kitab suci al-Qur'an.

Berangkat dari kesimpulan tersebut, dipahami bahwa objek tadabbur sebagaimana yang dijelaskan oleh al-Qur'an adalah al-Qur'an itu sendiri. Demikian ini juga mengingat bahwa kata yatadabbaru dalam al-Qur'an yang berarti berpikir atau menghayati hanya dikaitkan dengan alQur'an. Berikut sesuai dengan firman Allah:

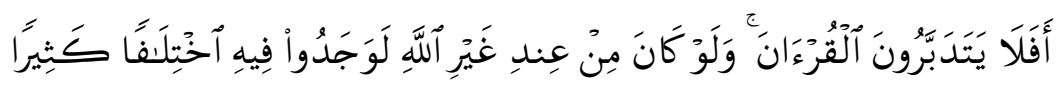

Terjemahnya:

"Maka tidakkah mereka menghayati (mendalami) al-Qur'an? Sekiranya (al-Qur'an) itu bukan dari Allah, pastilah mereka menemukan banyak hal yang bertentangan di dalamnya" (Depag RI, 2012: 92).

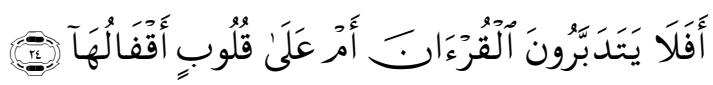

Terjemahnya:

"Maka tidakkah mereka menghayati al-Qur'an, ataukah hati mereka sudah terkunci?" (Depag RI, 2012: 510).

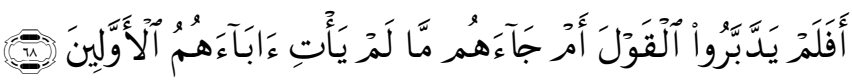

Terjemahnya:

"Maka tidakkah mereka menghayati firman (Allah), atau adakah telah datang kepada mereka apa yang tidak pernahdatang kepada nenek moyang mereka terdahulu?" (Depag RI, 2012: 347).

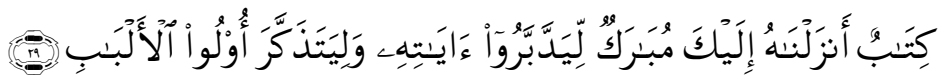

Terjemahnya:

"Kitab (al-Qur'an) yang Kami turunkan kepadamu penuh berkah agar mereka menghayati memperhatikan ayat-ayat-Nya dan agar orang-orang yang berakal sehat mendapat pelajaran” (Depag RI, 2012: 456).

\section{Perintah untuk Bertadabbur}

Al-Qur'an yang diturunkan oleh Allah Swt. tidak cukup hanya dipelajari dan dibaca. Kedua amalan tersebut belum cukup untuk dijadikan parameter dalam memahami ayat-ayat al-Qur'an. Oleh karena itu, mentadabburi ayat-ayat al-Qur'an yang meliputi rahasia-rahasia yang dikandung, segala sesuatu mengenai nama, sifat dan keagungan Allah swt., serta kabar dari al-Qur'an mengenai kisah para umat-umat terdahulu dari golongan mukmin dan kafir serta lainnya, menjadi hal yang penting untuk menambah pemahaman terhadap al-Qur'an.

Salah satu sifat al-Qur'an yaitu di dalamnya terdapat keberkahan, berkah yang terdapat pada setiap maknanya. Maka barang siapa yang mentadabburi al-Qur'an, niscaya dirinya akan mendapatkan keberkahan. Begitupula kepada orang yang mempelajari al-Qur'an, membacanya dengan sungguh-sungguh, mengamalkannya, mereka semua akan mendapatkan keberkahan. Allah Swt. berfirman: 


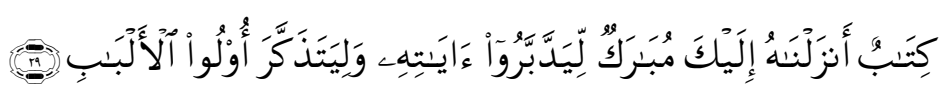

Terjemahnya:

"Kitab (al-Qur'an) yang Kami turunkan kepadamu penuh berkah agar mereka menghayati ayat-ayat-Nya dan agar orang-orang yang berakal sehat mendapat pelajaran" (Depag RI, 2012: 456).

Quraish Shihab memulai menafsirkan ayat ini dengan mengemukakan pandangannya mengenai perintah untuk memerhatikan kandungan al-Qur'an. Beliau menerangkan bahwa alQur'an yang diturunkan oleh Allah swt. dengan penuh berkah tersebut dimaksudkan agar mereka yakni umat manusia seluruhnya dan khususnya bagi mereka yang tidak percaya terhadap keberadaan al-Qur'an, memperhatikan ayat-ayatnya dan supaya orang-orang yang mempunyai pikiran cerah mendapat pelajaran (M. Quraish Shihab, 2009: 374).

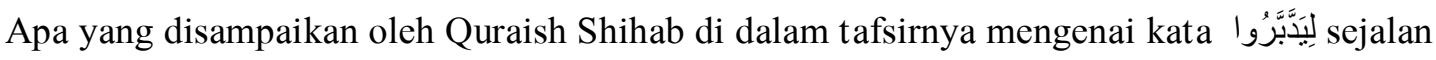
dengan pandangan bahwa al-Qur'an yang diturunkan kepada Rasulullah Saw. mengandung bimbingan yang sangat bermanfaat kepada umat manusia. Bimbingan itu menuntun manusia agar hidup sejahtera di dunia dan bahagia di akhirat. Dengan merenungkan isinya, manusia akan menemukan cara-cara mengatur kemaslahatan hidup di dunia. Tamsil ibarat dan kisah dari umat terdahulu menjadi pelajaran dalam menempuh tujuan hidup mereka dan menjauhi rintangan dan hambatan yang menghalangi pencapaian tujuan hidup. Al-Qur'an itu diturunkan dengan maksud untuk direnungakan kandungan isinya, kemudian difahami dengan pengertian yang benar, lalu diamalkan sebagaimana mestinya. Pengertian yang benar diperoleh dengan jalan mengikuti petunjuk-petunjuk rasul, dengan dibantu ilmu pengetahuan yang dimiliki, baik berhubungan dengan bahasa atau pun perkembangan masyarakat (Kemenag, 2010: 369).

Al-Qur'an tidak hanya direnungkan lalu kemudian difahami dengan benar, tetapi butuh pengamalan sebagaimana mestinya. Ibnu Kasīir (w. $774 \mathrm{H}$ ) dalam memahami ayat ini mengutip sebuah riwayat sebagaimana berikut ini (Ibnu Kasīir, 2005: 60).

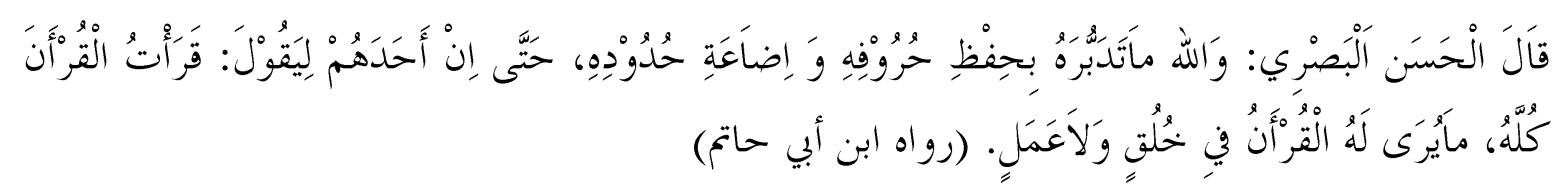

Artinya:

"Berkata Hasan al-Bașī: 'Demi Allah, tadabbur al-Qur'an bukan dengan menghafal hurufhurufnya namun mengabaikan batasan-batasannya, sehingga ada yang mengatakan, 'Aku telah membaca seluruh al-Qur'an,' namun al-Qur'an tidak terlihat pada akhlak dan amalnya".

Riwayat yang dikemukakan oleh Ibnu Kasiir (w. 1372 M) di atas, juga dikemukakan oleh Ibnu 'Utsaimin (w. 2001 M) bahwa tadabbur merupakan salah satu hikmah diturunkannya alQur'an. Tadabbur yakni dengan memerhatikan lafazh-lafazh al-Qur'an sehingga diketahui makna yang tersirat. Jika hal demikian tidak terwujud, maka hikmah dari diturunkannya al-Qur'an tidak 
pula tercapai dan kandungan yang terdapat pada lafaz-lafaz al-Qur'an tidak pula memiliki pengaruh.

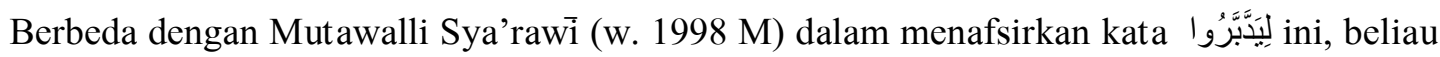
tidak menguraikan secara langsung tentang perintah untuk mentadabburi ayat-ayat al-Qur'an. Meski demikian, beliau kemudian menjelaskan dengan gamblang mengenai bagaimana cara bertadabbur yang baik. Menurutnya, tadabbur adalah tidak melihat sesuatu sekilas saja, tetapi melihatnya dengan penuh pertimbangan dan perhitungan, sebab akibat, baik dan buruk. Mutawalli Sya'rawi (w. 1998 M) pun memberikan permisalan sebagaimana kisah Nabi Musa dengan Nabi Khidir. Nabi Musa as. sempat marah saat Nabi Khidir merusak kapal. Sewaktu kapal tersebut dirusak oleh Nabi Khidir, Nabi Musa hanya berfikir bahwa tentulah kapal yang baik lebih bagus daripada kapal yang rusak. Demikian batas akal yang mampu dicerna olehnya saat itu. Sementara Nabi Khidir membandingkan antara kapal rusak dengan tidak punya kapal, bila kapal dirampas tentu rusak lebih baik dari pada diambil. Inilah tadabbur hingga terbuka rahasia alam gaib yang diberikan Allah kepada siapa saja dari hamba-Nya yang ikhlas beribadah kepada-Nya (Mutawalli Sya'rawi, t.th.: 451).

Demikian juga Sayyid Qutb (w. 1386 H) di dalam tafsirnya mengemukakan bahwa alQur'an yang penuh dengan keberkahan ini, yang diturunkan oleh Allah agar ditadabburi ayatayatnya oleh manusia. Beliau lebih lanjut menjelaskan bahwa tadabbur ini merupakan hal yang tak dapat digambarkan oleh orang-orang kafir, karena fitrah mereka yang tak bersambung dengan kebenaran yang murni dalam bangunan alam semesta ini. Karena kekafiran mereka itu juga, persangkaan mereka terhadap Tuhan mereka menjadi jelek, dan mereka tidak dapat menangkap dasar kebenaran sama sekali (Sayyid Qutb, 2004, 64).

Allah berfirman:

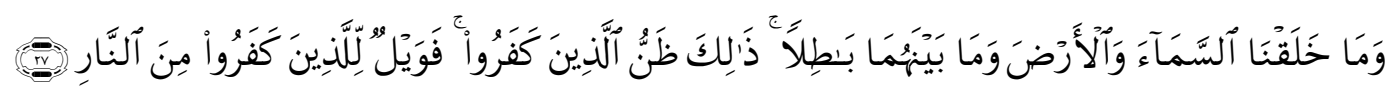

Terjemahnya:

"Dan Kami tidak menciptakan langit dan bumi dan apa yang ada di antara keduanya dengan sia-sia. Itu anggapan orang-orang kafir, maka celakalah orang-orang yang kafir itu karena mereka akan masuk neraka" (Depag RI, 2012: 456).

Para mufasir dalam menafsirkan ayat ini tidak hanya sebatas menafsirkan tentang tadabbur, tetapi juga memperhatikan kata مُبَرَكَ (berkah) yang menunjukkan keberkahan yang al-Qur'an miliki. Quraish Shihab misalnya, dalam menafsirkan kata مُبَرَكَُّ ini, beliau menjelaskan bahwa kitab tersebut penuh berkah karena yang menurunkannya adalah Allah Swt. yang merupakan sumber segala kebajikan, yang menerimanya adalah nabi Muhammad saw. yang mencerminkan dalam hidupnya segala macam kebajikan. Berkah kitab itu juga terdapat dalam kandungannya, kendati kalimat-kalimatnya sangat terbatas. Berkah dengan membacanya sehingga dengan mudah dapat dibaca bahkan dihafal oleh siapa pun walau mereka yang tidak mengerti artinya. Berkah dalam makna-makna yang dikandungnya karena al-Qur'an adalah sumber yang tidak kering, "yang 
tidak lekang oleh panas, tidak pula lapuk oleh hujan", sehingga betapapun ditafsirkan selalu saja ada makna baru yang belum terungkap sebelumnya. Berkah juga ia dalam pengaruh positifnya terhadap manusia serta dalam sukses dan keberhasilan yang diraih oleh yang mengamalkannya. Berkah juga dalam bukti-bukti kebenarannya, karena bukti-bukti itu terdapat dalam dirinya, melalui kalimat-kalimatnya serta langgeng bersamanya (M. Quraish Shihab, 2009: 374). Allah berfirman:

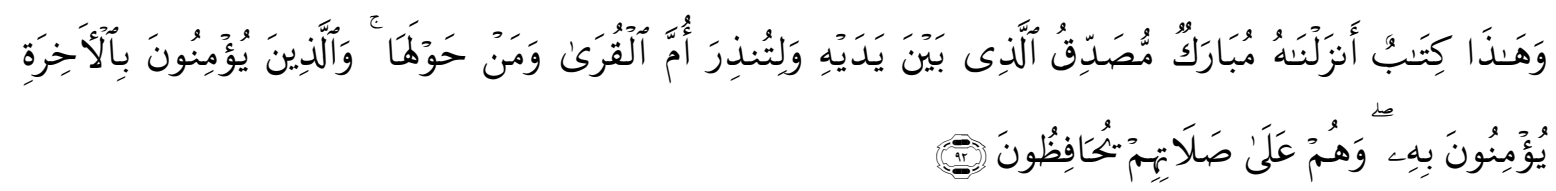

Terjemahnya:

"Dan ini (al-Qur'an), Kitab yang telah Kami turunkan dengan penuh berkah; membenarkan kitab-kitab yang (diturunkan) sebelumnya dan agar engkau memberi peringatan kepada (penduduk) Ummul Qurā (Mekah) dan orang-orang yang ada di sekitarnya. Orang-orang yang beriman kepadanya (al-Qur'an), dan mereka selalu memelihara salatnya" (Depag RI, 2012: 140).

Adapun makna kalimat ulul albāb, menurut Mutawalli Sya'rawī (w. 1998), maknanya adalah orang-orang yang memiliki akal yang cerdas. Pada ayat ini Allah menantang akal pikiran, Dialah yang menggerakkan akal untuk merenungi alam raya ini. Tantangan ini dilakukakan Allah karena Dia maha mengetahui bahwa hamba-hamba-Nya pasti akan sampai kepada-Nya melalui akal. Hal ini diumpakan seperti pedagang yang menjual barang berkualitas, dia akan menerangkan keistimewaan barang yang dimilikinya. Bahkan berani malakukan uji coba untuk mebuktikan keasliannya. Namun sayang, sebagian manusia saat berhadapan dengan perkara agama dia berkata: "ini dogma yang tidak logis.” Jawabannya: "Bukankah Allah memerintahkan kita untuk tadabbur, merenung, tafakur, berpikir pada alam raya ini, maka tidak ada salahnya kita meneliti (Mutawalli Sya'rawi, t.th.: 452).

Quraish Shihab lebih rinci menjelaskan kata al-albāb di dalam tafsirnya, yakni dimulai dari makna asal. Al-albāb adalah bentuk jamak dari al-lub, yaitu sari pati sesuatu. Kacang misalnya memiliki kulit yang menutupi isinya. Isi kacang dinamai al-lub. Ulul albāb adalah orang-orang yang memiliki akal yang murni yang tidak diselubungi oleh "kulit", yakni kabut ide yang dapat melahirkan kerancuan dalam berfikir. Yang merenungkan ayat-ayat Allah dan melaksanakannya diharapkan dapat terhindar dari siksa, sedang yang menolaknya pasti ada kerancuan dalam berfikirnya (M. Quraish Shihab, 2009: 375).

Dari beberapa penafsiran di atas, dapat diambil kesimpulan bahwa bertadabbur terhadap alQur'an merupakan sebuah perintah, karena al-Qur'an diturunkan untuk direnungkan isinya secara menyeluruh. Tidak hanya perintah untuk bertadabbur, tetapi juga dikemukakan mengenai bagaimana cara bertadabbur yang baik, yakni tidak melihat sesuatu sekilas saja, tetapi melihatnya dengan penuh pertimbangan dan perhitungan, sebab akibat, baik dan buruknya. 


\section{KESIMPULAN}

Setelah melakukan kajian terhadap makna tadabbur dalam al-Qur'an, dapat disimpulkan bahwa tadabbur adalah sebuah tingkatan tertinggi sebagai refleksi kecintaan kita terhadap al-Qur'an setelah sebelumnya membaca, menghafal, atau bahkan menafsirkan. Tadabbur bukan hanya sekedar aktifitas berfikir mendalam setelah membaca dan menghafal al-Qur'an, melainkan sebuah tindakan nyata dari setiap elemen yang al-Qur'an sajikan.

\section{DAFTAR PUSTAKA}

Al-Aḥdal, Hāsyim bin 'Ali. (2008). Ta'Tim Tadabbur Al- Qur'ān Al-Karīm. Makkah:Markaz adDirāsat wa al-Ma'lūmāt al-Qur'āniyyah.

Ibn Fāris. (2008). Maqāyīs al-Lughah. Kairo: Dār al-Hadits.

Ibn Manz̄ūr. (2003). Lisān al-Arab. Cairo: Dār al-Hadits.

Ibnu Kas̄ìr. (2005). Tafsìr Al-Qur’ān al- ‘Azìm. Cairo: Dār al-Hadits.

Kementerian Agama Republik Indonesia. (2012). Al-Qur'an dan Tafsirnya Jakarta: Kementerian Agama RI.

Munawwir, Ahmad Warson. (1997). Al-Munawwir Kamus Arab-Indonesia. Surabaya: Pustaka Progressif.

Muṣtafāa, Ibrāhīm, dkk. (t.th.). Al-Mu’jam al-Wasị̂t. Cairo: Dār ad-Da’wah.

Qụtb, Sayyid. (2004). Tafsir fỉ Zilāl Al-Qur'ān diterjemahkan oleh As'ad Yasin dkk. Jakarta: Gema Insani Press.

Shihab, M. Quraish, dkk. (2002). Ensiklopedi Al-Qur'an, Kajian Kosakata dan Tafsirnya. Jakarta: Yayasan Bimantara.

Shihab, M. Quraish, dkk. (2007). Ensiklopedia Al-Qur'an, Kajian Kosakata, Jakarta: Lentera Hati.

Shihab, M. Quraish. (2009). Tafsir Al-Mishbah, Pesan, Kesan, dan Keserasian Al-Qur'an. Ciputat: Lentera Hati.

Al-Suyūtịi, Jalāluddīn. (1974). Al-Itqān fỉ Ulūm Al-Qur'ān. Cairo: Hai'ah al-Mishriyyah al-‘Āmmah li al-Kitāb.

Al-Zamakhsyarì. (t.th.). Al-Kasysyāf 'an Haqā’iq at-Tanzìl. Beirut: Dār Kitāb al-Arab. 